\title{
OJED
}

Volume 5, Issue 1 (2020), pp. 52-75

International Journal of

Multidisciplinary Perspectives in Higher Education

ISSN: 2474-2546 Print/ ISSN: 2474-2554 Online

https://ojed.org/jimphe

\section{Foreign-Born Faculty's Perceptions and Experiences in a Turbulent Sociopolitical Climate}

\author{
Bita Bookman \\ Santa Rosa Junior College, California, USA
}

\begin{abstract}
This study investigated the experiences of five foreign-born faculty in the US after the 2016 election. Through a written questionnaire and semistructured interviews, the participants shared their recollections of several critical incidents, their reactions to Trumpism, and their perceptions of support from their institutions. The analysis of the critical incidents revealed that while the participants experienced varying degrees of collegial support and sense of isolation, for some, their concern with Trumpism impacted their intent to stay at their institution and in the US. The article concludes with recommendations to increase diversity in faculty body, training USborn faculty about diversity and inclusivity, and increasing systems of support for foreign-born faculty in order to increase the recruitment and retention of foreign-born faculty.
\end{abstract}

Keywords: Foreign-born faculty, Trumpism, recruitment, retention, critical incidents

“This country has turned really ugly to me." (Alia)

"This coming year we are considering Canada ... because I know that they are much more open to immigrants. They're much more open to people who look like me and my husband." (Maria) 
According to a report by the Institute for Immigration Research ${ }^{1}, 22$ percent or nearly 393,100 of the estimated 1.8 million postsecondary teachers in the United States are foreign-born, and nearly half of foreignborn educators work at the tertiary level (Furuya et al., 2019). The terms international and foreign-born are sometimes used interchangeably in the literature as studies often do not collect data on the immigration status of the foreign-born faculty. However, in this study, international refers to individuals who have a work visa which allows them to reside and work in the US for a specific period of time. Foreign-born, on the other hand, refers to any faculty who was not a US citizen at birth (United States Census Bureau, 2020) and includes those with a work visa, permanent residency status (green card), or US citizenship through naturalization. Foreign-born faculty are present in all institution types, but the highest concentration tends to be at research universities, in several arts and science fields, and especially in engineering (Mamiseishvili 2013; Mamiseishvili \& Rosser, 2010; Schuster \& Finkelstein, 2006).

In the increasingly competitive global market, recruiting and retaining highly skilled professionals have become crucial, and countries often have initiatives in place to attract professionals who can contribute to the competitiveness, growth, and prosperity of the country. To increase the faculty's embeddedness (Mitchell et al., 2001) or their intent to stay at their institutions, it is important to examine and understand their experiences and perceptions as well as the challenges they face in the current sociopolitical climate in the US. Using the Critical Incident Technique and examining prior incidents in their particular contexts, this study sheds light on the perceptions and experiences of five foreign-born faculty in teacher education and applied linguistics fields and the constraints they encountered in the era of Trumpism after the 2016 elections in the US. The following broad research question guided this study: What are the experiences of five foreign-born faculty in the current sociopolitical climate? Insights gained from this study can add to the body of knowledge in qualitative research, higher education, applied linguistics, teacher education, and educational leadership. Particularly, the findings and practical implications may be used by higher education institutions to enact policies and practices that could improve the on-campus lived experiences of foreign-born faculty and in turn facilitate their recruitment and retention.

\section{Literature Review}

${ }^{1}$ The Institute for Immigration Research is a research center at George Mason University. It examines the economic contributions of immigrants in the United States. 
Despite the substantial number of foreign-born faculty in the US, very little is known about their experiences and the challenges they face. However, the contributions of foreign-born faculty to the US higher education are evident in the limited available literature. First, foreign-born faculty play an important role in internationalization of higher education in the US (e.g. Ferren \& Merrill, 2013; Gahugu, 2011). Foreign-born faculty tend to co-author with peers from abroad more frequently (Finkelstein et al., 2009), and as Theobald (2013) argued, "widen perspectives on research and give voice to globalization in higher education" (p. 111). Similarly, Skachkova (2007) noted that the immigrant women faculty in her study "created international networks of knowledge and experience that contributed to the internationalization of American academia" (p. 729). Second, studies have shown that foreign-born faculty make exceptional contributions to science (Stephan \& Levin, 2001) as well as to the research productivity of universities as they tend to be more productive in research output than their native-born counterparts (Mamiseishvili \& Rosser, 2010; Webber, 2012). Third, several studies have shown that foreign-born faculty use their culture and worldviews as pedagogical resources and enable their students to see world events from a different perspective (Alberts, 2008; Bookman, 2019, Gahungu, 2011; Mamiseishvili, 2013; Skachkova, 2007). Research on students' perception of foreign-born professors shows that many students believe that foreign-born faculty "provide them with more than the regular classroom education by exposing them to different points of view, helping them to overcome stereotypes, and giving them first-hand insights into other places and people" (Alberts, 2008, p. 201). Fourth, as Mamiseishvili and Rosser (2010) argue, foreign-born faculty, when supported by their institutions, "can serve as role models to the growing number of international students" (p. 104). Similarly, female foreign-born faculty can be good role models for students, especially for female students in fields where women are underrepresented (Skachkova, 2007). In Skachkova's study (2007), for instance, being able to identify with students from different countries and cultural backgrounds, foreign-born faculty express a strong sense of empathy for their students which they credited to their own personal experience of overcoming obstacles in adjusting to the US.

Despite these contributions, foreign-born faculty encounter unique challenges as they navigate the US education system and way of life (Alberts, 2008; Collins, 2008; Foote, 2013; Foote et al., 2008; Gahungu, 2011; Skachkova, 2007). Often perceived as enjoying an elite and privileged status as college professors, foreign-born faculty in the US are not immune to challenges and marginalization. For instance, in comparison to their USborn counterparts with the same qualifications, for instance, in comparison to their US-born counterparts with the same qualifications, foreign-born faculty often face a glass ceiling in relation to authority and leadership 
positions (Skachkova, 2007; Tang, 2000; Varma, 2006). Being perceived as outsiders, foreign-born faculty in the US often also experience a sense of isolation in the academic community (Foote et al., 2008) and may be sidelined as they face discrimination and segregation in their teaching, research, and service (Skachkova, 2007). For instance, Skachkova's (2007) research participants noted that they were excluded from leadership roles, their previous leadership experience in their home countries was not recognized in the US, and the committees they were placed in "did not give them the opportunity to make a real change" (p. 718). In addition to a lack of differentiated support on campus (Foote et al., 2008), foreign-born faculty may experience a sense of loneliness and cultural challenges such as difficulty integrating into their host society, institution, and less-diverse communities surrounding their campus (Collins, 2008; Murray, 2007; Skachkova, 2007) although research has shown that support programs such as mentorship and socialization opportunities may facilitate the foreign-born faculty's integration into their new community (Bland et al., 2009; Espino \& Zambrana, 2018; Fountain \& Newcomer, 2016; Hildebrandt \& Swauger, 2016; Zambrana et al., 2015). While foreign-born faculty are more likely than their US-born counterparts to form collaborative networks outside their university as well as internationally, this broader external network has been shown to index the isolation and lack of equal opportunities they experience within their own institutions. For example, in Skachkova's (2007) study, immigrant women faculty "were segregated to teach courses and research topics that were bonded to their ethnic, national, or regional background. This affected their teaching credibility regarding U.S.-based topics, which was further reinforced by their accents" (pp. 728-29). These discriminatory practices on campus provide a plausible explanation for why foreign-born faculty may be more likely to seek and form academic networks outside their own departments and institutions. Studies have also shown that foreign-born faculty tend to be less satisfied with their jobs compared to their US-born colleagues (Kim et al., 2011; Mamiseishvili \& Rosser, 2010). Some of these challenges are similar to the racial microaggression and discrimination black faculty and other faculty of color in the US experience in terms of tenure and promotion (e.g. Witherspoon Arnold et al., 2016), marginalization, bias in hiring, unfair work expectations, and accent discrimination (e.g. Turner et al., 2008). However, foreign-born faculty also face unique challenges, for instance the need for assistance with the visa process and support with adjusting to US customs for classrooms, their departments, and research and funding opportunities (Foote, 2013).

This article is a part of a larger qualitative research project in response to Favell et al.'s (2007) call for more empirical studies on skilled migrants and Foote et al.'s (2008) and Mamiseishvili's (2013) calls for more research on foreign-born faculty, especially in humanities, social sciences, and education fields. It explores the obstacles foreign-born faculty may 
encounter within their social and professional communities in the current sociopolitical climate. Because individuals' experiences must be contextualized within broader societal structures or normative discourses (e.g. Guarnizo \& Smith, 1998; Purkayastha, 2005; Waldinger, 2008), this study situates the participants' micro experiences within their sociopolitical contexts, and more specifically, Trumpism. While there are different definitions for Trumpism, in this paper I define it as "alt-right forces that, marginalized for decades, are bringing bigotry, patriarchy, nativism, and nationalism back into a visible place in the American civil sphere" (Alexander, 2019, p. 5). This alt-right ideology is manifested in Donald Trump's rhetoric and policies, such as his insult on Mexicans, executive order banning travel from seven predominantly Muslim countries, disparaging comments about developing countries, long term immigration detention centers and separating children from their parents, attempting to end Deferred Action for Childhood Arrivals, and significantly decreasing refugee admissions (National Immigration Law Center, 2019; Schmidt, 2019). The above rhetoric and policies, among others, have exacerbated a climate of racial conflict and xenophobia and have brought race and immigration to the forefront of the public and social justice discourse.

\section{Theoretical Framework}

The data in this study was collected and interpreted through the application of the critical incident technique. A critical incident is defined as any occurrence, positive or negative, that has significance to an individual for whatever reason. Because critical incidents represent events that have had a lasting effect on a person, they can be information-rich sources. For instance, in a study about the experiences of recovering alcoholics, Denzin (1987) asked the participants to talk about critical moments in their lives in relation to their addiction and rehabilitation process, noting, "uncovering the meanings to the pivotal event in their lives was a key to understanding how they became recovering alcoholics" (Denzin, 2014, p. 48). The Critical Incident Technique (CIT), however, involves more than just a description of a past event. I adopt Tripp's (2012) approach in that:

critical incidents are not 'things' which exist independently of an observer and are awaiting discovery like gold nuggets or desert islands, but like all data, critical incidents are created. Incidents happen, but critical incidents are produced by the way we look at a situation: a critical incident is an interpretation of the significance of an event. To take something as a critical incident is a value judgement we make, and the basis of that judgement is the significance we attach to the meaning of the incident. (p. 8)

Thus, a critical incident is constructed when a prior incident is examined in its particular context, its significance is recognized, and conclusions are offered. Furthermore, as Tripp (2012) elucidates, critical incidents are not 
"all dramatic or obvious: they are mostly straightforward accounts of very commonplace events ... These incidents appear to be 'typical' rather than 'critical' at first sight, but are rendered 'critical' through analysis" (pp. 2425).

To increase the participants' engagement with the questionnaire, I invited them to present their critical incidents in any form or genre they preferred; for instance, by drawing, creating a collage, writing narratives, poems, or prose, including a photograph, or using a combination of these forms. As Atkinson (2002) urged, "What is important is that the life story be told in the form, shape, and style that is most comfortable to the person telling it" (p. 125). However, art forms such as poems do not always express their author's intended meaning. Therefore, during the interviews, I asked the participant who had used poems in her critical incidents to explain what she intended her poems to signify. My goal during the interviews was to have the participants go beyond simple description of the events and to provide me with their interpretations.

\section{Methods}

This study reports several threads from a dissertation project that investigated the lived experiences, perceptions, and practices of five foreignborn faculty in the US. This article focuses on a portion of the findings related to the sociopolitical climate and collegial support. Using purposeful, convenient, and criterion-based sampling, I identified five individuals I knew through a professional association for teachers of English as a second language. The criteria for selection consisted of being 1) foreign-born, and 2) a faculty member in a higher education institution in the US. Alia, from Europe, Kayoko, from Japan, and Maria, from Brazil, and Chatri from Thailand were all tenured faculty while Ismail, from Turkey, was pretenured $^{2}$. Kayoko, Maria, and Chatri were in their 40s while Alia was in her 50s and Ismail was in his 30s. All five participants were PhD holders, lived and worked in a southern or southwestern state, and taught Teacher Education and/or Applied Linguistics to graduate students. All, other than Alia, taught at R1 universities. Alia, Kayoko, and Maria were US citizens and held department-level leadership positions, Chatri was a green card ${ }^{3}$ holder, and Ismail was on a work visa waiting for his green card interview. Table 1 presents an overview of the participants.

Table 1: Research Participants Overview

\footnotetext{
${ }^{2}$ All names are pseudonyms.

${ }^{3}$ The green card is the legal documentation given to US permanent residents before becoming US citizens.
} 


\begin{tabular}{|c|c|c|c|c|c|c|c|}
\hline $\begin{array}{l}\text { Pseudo } \\
\text { nym }\end{array}$ & $\begin{array}{l}\text { Country } \\
\text { of Birth }\end{array}$ & $\begin{array}{l}\text { Age/ } \\
\text { gender }\end{array}$ & $\begin{array}{c}\text { Race/ } \\
\text { Ethnicity }\end{array}$ & $\begin{array}{l}\text { In } \\
\text { the } \\
\text { US } \\
\text { Since }\end{array}$ & $\begin{array}{l}\text { Location } \\
\text { in the } \\
\text { US }\end{array}$ & $\begin{array}{c}\text { Title/ } \\
\text { Institution }\end{array}$ & $\begin{array}{c}\text { US } \\
\text { Citizenshi } \\
\text { p Status }\end{array}$ \\
\hline Alia & Europe & $\begin{array}{l}\text { Early } \\
50 \mathrm{~s} / \\
\text { female }\end{array}$ & $\begin{array}{c}\text { White/ } \\
\text { Europea } \\
n^{4}\end{array}$ & $\begin{array}{l}\text { Late } \\
1980 \\
\text { s }\end{array}$ & South & $\begin{array}{c}\text { Professor, } \\
\text { Department } \\
\text { Administrator/ } \\
\text { Private Liberal } \\
\text { Arts College }\end{array}$ & US Citizen \\
\hline $\begin{array}{c}\text { Kayok } \\
\text { o }\end{array}$ & Japan & $\begin{array}{c}\text { Mid } \\
40 \mathrm{~s} / \\
\text { female }\end{array}$ & $\begin{array}{c}\text { Asian/ } \\
\text { Japanese }\end{array}$ & $\begin{array}{l}\text { Late } \\
1980 \\
\text { s }\end{array}$ & $\begin{array}{c}\text { Southwe } \\
\text { st }\end{array}$ & $\begin{array}{l}\text { Associate } \\
\text { Professor \& } \\
\text { Program } \\
\text { Director/ } \\
\text { R1 }\end{array}$ & US Citizen \\
\hline Maria & Brazil & $\begin{array}{c}\text { Mid } \\
40 \mathrm{~s} / \\
\text { female }\end{array}$ & $\begin{array}{c}\text { Latinx/ } \\
\text { Brazilian }\end{array}$ & $\begin{array}{c}\text { Mid } \\
1990 \\
\text { s }\end{array}$ & South & $\begin{array}{c}\text { Professor \& } \\
\text { Department } \\
\text { Chair/ } \\
\text { R1 }\end{array}$ & US Citizen \\
\hline Chatri & $\begin{array}{c}\text { Thailan } \\
\text { d }\end{array}$ & $\begin{array}{l}\text { Mid } \\
\text { 40s/ } \\
\text { male }\end{array}$ & $\begin{array}{l}\text { Asian/ } \\
\text { Thai }\end{array}$ & $\begin{array}{l}\text { Mid } \\
2000 \\
\text { S }\end{array}$ & $\begin{array}{c}\text { Southwe } \\
\text { st }\end{array}$ & $\begin{array}{l}\text { Associate } \\
\text { Professor/ } \\
\text { R1 }\end{array}$ & $\begin{array}{l}\text { Green } \\
\text { Card } \\
\text { Holder }\end{array}$ \\
\hline Ismail & Turkey & $\begin{array}{l}\text { Mid } \\
30 \mathrm{~s} / \\
\text { male }\end{array}$ & $\begin{array}{l}\text { Middle } \\
\text { Eastern/ } \\
\text { Turkish }\end{array}$ & $\begin{array}{c}\text { Late } \\
2000 \\
\text { s }\end{array}$ & $\begin{array}{c}\text { Southeas } \\
t\end{array}$ & $\begin{array}{l}\text { Assistant } \\
\text { Professor/ } \\
\text { R1 }\end{array}$ & $\begin{array}{c}\text { Work Visa } \\
\text { (Green } \\
\text { Card in } \\
\text { process) }\end{array}$ \\
\hline
\end{tabular}

After obtaining the IRB approval and informed consent from the participants, I began data collection first by a written questionnaire, followed by two semi-structured interviews with each participant, 60-90 minutes long each. The questionnaire collected biographical information, asked several questions related to the current sociopolitical climate, and prompted the participants to narrate several critical incidents they had experienced. The parts of the questionnaire this article is focusing on are presented in the Appendix. Then, during the interviews I asked the participants to expand on and clarify their responses to the questionnaire.

After the interviews, I transcribed them verbatim using a "broad transcription" (Du Bois et al., 1993, p. 45). I read and re-read the data and analyzed them to make sense of the participants' experiences, to make inferences, and to offer explanations (Patton, 2002). I was particularly interested to see if the findings align with what the literature shows about foreign-born faculty's job satisfaction and the challenges they face in their

${ }^{4}$ Alia requested that I use 'European' as her place of origin instead of the specific European country to further protect her confidentiality. 
workplace and communities. I identified quotes that represented each participant's experiences and made interpretations as to what they entailed. I then carried out member-checking (Lincoln \& Guba, 1985) to ensure that the interview transcripts and my interpretations of the participants' critical incidents accurately reflected what the participants intended. My analysis yielded four overarching themes of 1) perceptions about Trumpism, 2) continuum of collegial support, 3) feeling of not being good enough, and 4) sense of isolation. I present these themes below.

\section{Findings}

\section{Perceptions about Trumpism}

The racism and xenophobia in the current sociopolitical climate in the US had an emotional impact on Alia, Maria, Chatri, and Ismail, to varying degrees. All participants expressed concern about the direction in which the country was going. Alia's and Maria's deep concern had led them to consider relocating to another country if Trumpism continued.

Alia described that she was deeply disturbed by the political events, for example when she watched the meeting between the US President Donald Trump and the Russian President Vladimir Putin on TV in 2018:

I saw the live interview when it happened, and I cried. I said: 'this is so terrible'; I don't even know what to say. My mom is a refugee from [a country in Eastern Europe], she grew up under the Russians ... Where they lived, all the women were raped and many kids were raped, and she's a refugee and I'm thinking who in their right mind would look at a Russian $\mathrm{KGB}^{5}$, former KGB boss to look [at him] as a friend? I mean I'm also offended by that.

Alia was also extremely concerned about the rise of white supremacy in the US. She believed that even though racism had always existed, "at least people had to work on overcoming it, but now it's okay". Because of the sociopolitical change in recent years, Alia had learned about the xenophobic views of many individuals around her, which she found horrifying:

People can channel all the racism now, attacking people on the street and openly finding it okay to discriminate ... [Trump] opened this Pandora box ... this country has turned really ugly to me because even people that I thought were good people are horrible people and come out of the wardrobe now.

Alia was considering leaving the US if Trumpism continued:

We haven't acted on that but if it goes on in the future, we may [leave]. I'm not afraid of starting over somewhere else. So, I have friends in Australia, in all kinds of countries. I would definitely keep

\footnotetext{
${ }^{5}$ KGB (Komitet Gosudarstvennoy Bezopasnosti) translates to "Committee for State Security" in English and was the secret police force in the Soviet Union.
} 
that option. We even looked into other jobs abroad, like in the Middle East.

Maria, too, was concerned about the political climate in the US. She believed that she was personally impacted by it because her work was directly connected to immigrant children and their education:

It's so sad, it's so draining... I feel like for the past couple of years it has had an effect both on me and my husband and how we feel ... what is happening now on the borders and people taking kids and separating kids from their parents and all of this, it's just disheartening. So it really drains you, it drains you and that's why I feel like I'm also getting more tired. ... Even if I sleep, the next day I'm still tried, and I think it does have some connection to what is going on in politics.

She added:

This coming year, we are considering Canada ... because I know that they are much more open to immigrants. They're much more open to people who look like me and my husband ... We definitely want to go to a place that is ... more democratic.

Similarly, the sociopolitical climate during and after 2016 elections made Chatri feel uncertain about his future in the US. Describing the unpredictability of immigration policies, he explained:

Speaking of politics, right now it's not really a good time, specially for immigration or people who come from other countries because with one signature everything can, just like "poof", [be] gone, right? So we can be legal now and then in a few days you're like "no, you're done". We have to watch out for a lot of things.

Ismail described his thoughts about the political climate as follows:

Personally I feel really, really sad about this country getting into that direction, and I can see what's going on here is very similar to Turkey because people are getting emotionally manipulated or the leaders are using people's emotions to govern them and they're using religion, they're using patriotism ... they're abusing people's emotions about, like, flag or country.

Ismail also explained that the new vetting policies by Trump administration, requiring applicants to submit additional information and attend interviews have made it more challenging for him to obtain his green card:

It's probably because of the new government that my green card is taking longer and I'm going to have to go through an interview because now everybody is going through interview. In the past, it was just very few people, they just picked randomly ... but now everybody is.

As these quotes illustrate, for all participants other than Kayoko, the current sociopolitical climate amid Trumpism was a source of concern and, to 
varying degrees, had led them to contemplate leaving the US for a safer, more immigrant-friendly country.

\section{Continuum of Collegial Support}

Collegial support was a recurrent theme that emerged in the critical incidents of all the participants. However, the degree to which each participant reported receiving support was different. Maria stated:

For the most part, most of my colleagues really, really respect me and because they know my knowledge base, they know that I know my stuff and I have knowledge that they don't and experiences that they don't. I think that, for the most part, I'm really very wellrespected by my colleagues.

Similarly, Kayoko claimed:

I just feel really fortunate ... I had really supportive colleagues who just looked out for me and advocated for me. They made it very clear from the beginning for example that they wanted me to get tenured. ... there was definitely a culture to protect junior faculty ... and that made me feel comfortable asking questions and I could always find people who could help me.

As foreign-born women faculty of color, Maria and Kayoko claimed that they had never felt that they were treated differently because of their ethnic, racial, linguistic, or foreign-born identities. When Kayoko was assigned to a committee she did not enjoy, she did not attribute it to her foreign-born or identities. Similarly, Maria reported that her presence in committees was always welcomed and her voice was always heard. In addition, Kayoko recalled that at her first institution, when she felt she needed much support linguistically and academically, she found a great deal of mentorship and compassion among her colleagues. Maria also spoke highly of her administrator who advocated for her at the university level. The findings from Maria and Kayoko's narratives contradict some of the existing literature on marginalization of women and women of color in academia (e.g., Lin et al., 2004; Motha \& Varghese, 2016; Skachkova, 2007; Toth, 2007); however, both Maria and Kayoko acknowledged that the level of collegial support they had been receiving was not always provided to all foreign-born faculty, women faculty, and faculty of color in other departments and institutions.

Ismail and Chatri, too, reported supporting working environments. However, Chatri expressed concerns about lack of leadership opportunities for foreign-born and minority faculty at his institution:

In my college, we had this conversation a few years ago about the lower participation of foreign nationals or foreign-born faculty in the administrator level and there were some training ... My department is very diverse. We have people from different countries ... many of us are bilingual ... [but] the faculty of color [have] had 
limited opportunity to climb the administrative positions and the dean had sort of initiatives and that conversation has died down but I feel like it is sort of true ... if I'm to think about department chairs of the one that I know, or the deans that I have seen, the majority of them would be white American ... Not so much of Latin or African American or Asian. I know only one who is department chair who is Asian here in this university.

Ismail at times felt like a "diversity token" because on two occasions he was assigned courses on diversity and multiculturalism which did not align with his areas of specialization. Nevertheless, he stated that he felt his voice was heard in department meetings. His concern, however, was in regard to issues of his assigned identity as a foreign-born faculty member and that his colleagues often focus on his ethnic identity instead of his professional identity:

I had conversations with another faculty from Turkey who was hired in the same year as me and we agree that we feel uneasy when people approach us and start telling us about what they know about Turkey or asking us questions about the current events in Turkey, as a conversation opener, I guess. We expect to be positioned more than just a Turkish guy/faculty. ... It was a narrative I remember, like, you're from Turkey, so I've been there or my husband's been there, or my cousin has been... I mean, okay, that could be a nice introduction or nice entry point but then, I'm not saying that I want to deny my home country, but the thing is: here I'm at the university, not because I'm from Turkey, I'm at the university because I have a degree and I have been hired to work here ... It's those macro sociological identities that people assign to you automatically.

While Kayoko described her institution and colleagues as supportive, she narrated a critical incident in which she was criticized for focusing her work on Japanese speaking participants:

It was the $3^{\text {rd }}$ year review on my job as a tenure-track assistant professor. My review was overall positive, but ... two comments in particular really surprised me. One was "when would [Kayoko] move on and start studying people who are not like herself?" It referred to the fact that my research focused on English language learners in different contexts (including but not limited to the US and Japan) and the particular project I was working on then was about international teaching assistants. I told my mentor that there was actually an entire field of TESOL $^{6}$ dedicated to studying "people like me," comprised of people "who are and are not like me."... The second comment, which annoyed me quite a bit, was

${ }^{6}$ TESOL stands for Teachers of English to Speakers of Other Languages. 
that some of my colleagues felt I was "getting an easy way out" by conducting studies using Japanese... I wanted to point out that I was then publishing it in English, my L2 ${ }^{7} \ldots$ so I really did not see how I was getting anything easy.

In contrast to the other participants, Alia spoke of a hostile work environment where she did not feel welcomed, supported, or valued. Despite being an administrator in her department, Alia believed that her institution denied her opportunities to obtain higher-level leadership positions beyond her department:

When there's new positions coming for leadership on campus, I know that I'll never have a chance ever ... I know that there's this ceiling that I cannot penetrate upwards. When I have good ideas of what we can do on campus, [the administrator] doesn't even listen to me.

When a college-wide administrative position became available, three senior faculty members in Alia's department encouraged her to apply for the position. When Alia submitted her application, one administrator was not pleased: "The administrator was criticizing me and said, wow, everyone else only did one page, you did like a whole dossier. Now I have to ask them to go back and rewrite theirs". Alia was confused because, as she put it, "each person submitted what they wanted, ... you could submit as much as you want". Alia also felt like an outsider at work. For example, Alia described that when the faculty members in her department had lunch together and engaged in conversation, she did not always feel like she was a part of the group:

There's always something that makes me feel [like] 'the other'. When they look at my food or whenever ... it's not always coming from a good place. They're all patriots, you know. And I'm thinking I'm less of an American than they are in their eyes.

For example, Alia described that at the beginning of every new academic year, her institution had a retreat where they played a game based on TV shows and characters, which Alia did not know because she did not grow up in the US.

It's like you cannot remind them in any way that you're not exactly the same because they don't like that. So, it just makes me feel very lonely and a lot of time like outside of the group ... I have to completely fit the structure ... there is no space to carve out a different mold. It's like cookie cutters; you have to fit exactly in that cutting hole and not make your own holes.

Because the degree of collegial support the participants experienced varied, it can be interpreted as a continuum. On one end of the continuum were Maria and Kayoko who claimed to have received a generally high level of

${ }^{7}$ L2 stands for second language. 
support from the institutions they had worked at. On the opposite end of the continuum is Alia who recounted several critical incidents in which she felt she was marginalized and excluded from social gatherings and an institution-wide leadership position. In the middle of the continuum are Chatri who reported a glass ceiling for minority faculty at his institution and Ismail who felt he was hired as a diversity token and his Turkish identity was often foregrounded by others over his researcher and scholar identity.

\section{Feeling of Not Being Good Enough}

An interesting phenomenon emerging from Maria's and Ismail's data is their feeling of not being good enough which led them to "do more" by maintaining a higher research output than their US-born counterparts. Maria described:

Especially in graduate school and in my first few years as an assistant professor, I felt like I had to show to get tenure: "oh it's not [enough] having like 10 refereed journal articles, I need to have 30" ... otherwise, whoever's reviewing my case or the university, my colleagues, they're not going to think that I'm good enough... it really was important to show that I really am the best in my field because that was the requirement for the green card. ... I have always felt that way that I really need to be the most productive to show that it's okay for me to be here.

Likewise, Ismail explained:

[Even though] I don't feel pressured much, ... comparing myself with the domestic scholars, I feel like I need to do more ... It's a complex that I have, that I need to compensate [for] something, like I'm not from here ... I need to do the best that I can.

This finding is consistent with the literature that has found higher research productivity in foreign-born faculty compared to US-born faculty (Mamiseishvili \& Rosser, 2010; Webber, 2012). As demonstrated in these quotes, Maria and Ismail did not attribute their feeling of not being good enough to pressure from their institutions or colleagues, rather, they felt that they needed to do more than their US-born colleagues in order to continually earn their position in the academe in the US.

\section{Feeling Isolated}

Chatri, Ismail, and Alia expressed a sense of loneliness as an academic in the US. Chatri, for instance, stated:

Making friends ... is a little more difficult ... So people have different lives, families, kids, and those kind of thing, so it is hard to have a friend that you can talk to or go out and hang out with once in a while.

Chatri added that without mentorship, it would be difficult for foreign-born faculty to feel supported: 
I think the institutions need to provide more support, especially emotional support ... we hire them but there's no support system in terms of inviting them to make more friend or having mentorship ... and they feel isolated. They wouldn't feel welcomed, and in the end, they would just leave for another place where they feel supported and welcome.

He described the mentorship program at his own institution and how it helped him feel connected:

When I first got in, I was paired up with a full professor from another department, and I felt we can talk about anything at all because he is not from my department, so I can actually talk about other things life in the university ... I felt very supported because of that.

Similarly, Ismail expressed a difficulty forming meaningful relationships:

I'm not saying that I don't have meaningful relationships but most of the people I see, I see them at meetings only ... The relationships are usually pretty superficial at the professional level ... building relationships takes time and most of the time ... it's really easy to feel isolated in academia. ... you can just come here, close your door, and do whatever you do on your computer. That's not healthy. ... I hear stories from other colleagues, from other universities where they have more workshops where people just go and have fun and just interact and communicate with people, just talk about fun things.

Alia, too, expressed feeling lonely but traced the cause of her loneliness to the unwelcoming environment her colleagues had created for her as a foreigner with a different culture, as she stated in her quote in the section about her colleagues' attitude toward her.

For Kayoko described feeling lonely at her previous institution due to a lack of diversity in both the university and in the surrounding community, which caused many foreign-born minority faculty to leave:

What [my university] does is that it does hire a lot of scholars from diverse backgrounds, ... So I think when new faculty comes here, it's not so hard for any of us to find someone at the senior level that look like us or that sound like us ... and I think that makes a big difference. At [my previous university], faculty was very white and ... hiring wasn't so difficult but retaining ethnic minority faculty ... they often ended up moving to other institutions saying that they didn't feel quite at home, like they didn't fit in. And I don't think ... it's the problem of the institution only. The surrounding community was very white. So I think it went beyond workplace issue. They just felt really out of place every single day.

Kayoko then emphasized the importance of diversity in both the institution and the surrounding community in retention of foreign-born faculty: 
[In my current institution] I know that there are multiple groups that I could belong to ... I do belong to some of them and that does give me connection to other people on campus who share the same concern, whether it's the gender issue or whatever. So it might be helpful to have these official or unofficial groups that faculty feel they can be part of and then they can meet people ... and there could be some unofficial mentoring ... finding people who are similar to me or finding someone who are similar to you, I guess for me that's a big thing.

As seen in these quotes, the participants claimed various causes for their sense of isolation: lack of racial and ethnic diversity on and off campus, work culture of academia which prioritizes research productivity over personal relationships, and nationalist attitudes toward foreigners.

\section{Discussion and Implications}

The findings in this study must be interpreted in tandem with three main limitations. The first limitation involves the sampling as the study did not feature black participants, particularly from non-Arab African nations. Studies have shown that black faculty often experience challenges such as microaggression, lack of collegial support, and increased scrutiny in hiring, tenure, and promotion. Including black participants in this study would have generated a richer and more complete perspective on the intersectionality of race and academy for the foreign-born faculty in the academy in the US. The second limitation of this study is that the description of the participants' lived experiences in this study is complete to the extent that they felt safe and comfortable sharing them with me. Although my familiarity with the participants and our shared experiences as foreign-born faculty based in the US and members of the same professional association provided us with a certain degree of closeness, due to the personal, political, and sensitive nature of the interviews, I sensed varying degrees of reservation on the part of the participants when sharing their experiences and perceptions about their institutions and colleagues. Third, because the focus of this study was the experiences and perceptions of the participants as foreign-born faculty, the interview questions prompted the participants to reflect on their experiences only as foreign-born faculty. As a result, the data did not yield insight about the intersection of race or gender as prominent identity constructs in the experiences of the participants. I now realize that overlooking the intersectionality of race, gender, foreign-born identity, and academia may have caused me to miss important aspects of the participants' experiences. Future studies may avoid these shortcomings by including more black foreign-born faculty and by using a Critical Race Theory or Feminist theory to examine the intersection of race and gender with issues that foreign-born faculty face. 
Despite these limitations, several insights can be gleaned from this study. Most participants expressed concern regarding Trumpism and the future direction of the US, and some considered leaving the US if Trumpism continued. In addition, the participants experienced varying degrees of support from their colleagues, and some felt a sense of isolation in their workplace. Among the three participants who described a lack of support to varying degrees, Alia attributed her sense of disconnectedness to the cultural bias and nationalist ideology of her colleagues, and Chatri and Ismail explained that their isolation is due to the systemic culture of academia which prioritizes research productivity over all other activities. The findings in this study parallel similar findings by Collins (2008), Foote et al. (2008), and Skachkova (2007), who reported that loneliness is one of the challenges encountered by foreign-born faculty. Additionally, while Maria and Kayoko claimed that they felt they had never been treated differently because of their racial identities, Chatri and Ismail alluded to racial tension when Chatri spoke about limited leadership opportunities on his campus and Ismail described being positioned as the diversity hire and a Turkish person rather than a scholar. This parallels the research findings that certain challenges may be intensified for foreign-born faculty of color in the academe (e.g. Skachkova, 2007; Tang, 2000; Turner et al., 2008; Varma, 2006; Witherspoon Arnold et al., 2016).

The practical implications presented below are divided into two categories: a) ways to increase diversity in faculty body through recruitment and retention of more foreign-born faculty and b) training US-born faculty and creating systems of support for foreign-born faculty.

\section{Increasing Recruitment and Retention of Foreign-Born Faculty}

Disconnectedness and loneliness can play an important role in foreign-born faculty's embeddedness (Mitchell et al., 2001) in their institution, negatively impacting retention. One way institutions can increase the sense of community for foreign-born faculty is to increase diversity on campus by hiring a more diverse faculty body. When an institution is located in an area that lacks racial and ethnic diversity, the area surrounding the campus may not offer the cultural and social advantages that larger, more diverse cities can offer, thus affecting the recruitment of diverse faculty such as foreign-born faculty or faculty of color (Cejda, 2010; Murray, 2007). One way to facilitate recruitment of minority faculty is by involving current minority faculty in the recruitment process. As foreignborn faculty tend to engage in research projects with international collaborators (Bookman, 2019, Skachkova, 2007), the professional network of the current foreign-born faculty may be a rich source for identifying future faculty members.

Another way to increase recruitment of diverse faculty is establishing a student-to-faculty pipeline. Starting from undergraduate 
programs and continuing on to graduate programs, institutions can make a commitment to recruiting, mentoring, and cultivating a diverse student body as potential future faculty. This pipeline will provide the institution highly qualified, diverse candidates for faculty positions once they earn their graduate degrees.

Another type of pipeline for hiring diverse faculty can be established through teaching fellowship programs. Murray (2007) has several suggestions in the context of rural community colleges which may be useful for other kinds of institutions in less diverse areas. For instance, he suggests creating a teaching fellowship program where new graduates or graduate students completing their dissertations are offered teaching fellowships consisting of a temporary faculty position, mentorship, and the opportunity to gain experience. This teaching fellowship program could then lead to permanent positions for the teaching fellows.

A third way to create a pipeline is by keeping track of student alumni. Former students may welcome the opportunity to return to and teach in their former community (Murray, 2007), and returnee students are more likely to be familiar with and have realistic expectations about the cultural and social norms of the institution and the surrounding area. As Murray (2007) argues, "individuals whose expectations are met tend to have higher job satisfaction, and those with higher job satisfaction are ... more committed to the organization, and have longer tenures" (p. 60). Therefore, recruiting foreign-born alumni may allow a relatively easier adjustment for the foreign-born faculty as it allows the returning faculty and the campus community to tap into and continue to build on the relationship they had already established.

But, merely recruiting diverse faculty does not ensure their retention. In addition to the recruitment initiatives proposed above, several actionable plans could be implemented to increase the retention of diverse teacher-scholars by increasing their connectedness to their community both on and off campus. First, it is important to provide specifics about the geography, demographics, and cultural attributes of the area surrounding the campus during the recruitment process. Including this information in job advertisements and discussing it with job candidates during interviews can manage potential candidates' expectations and increase their retention. As Leist (2007) claims, "the lack of specificity can prevent a good fit" (p. 35).

\section{Training US-Born Faculty and Creating Systems of Support for Foreign-Born Faculty}

Providing regular opportunities for informal one-on-one talks among all faculty, as Ismail suggested, can allow administrators to connect with minority faculty on a personal level, to inquire about their well-being, and to learn about the ways the faculty can be better supported. 
Alternatively, regular focus groups may be used to elicit minority faculty's perceptions about issues that are important to them.

Alia's experiences highlights the importance of institutional training and professional development on diversity and equity issues such as implicit bias and prejudice, effective cross-cultural communication, and how USborn faculty can foster welcoming academic communities for their foreignborn peers. Trainings can focus on tangible and practical issues, for instance, that in social gatherings such as faculty retreats, it is important to choose activities that are inclusive and sensitive to the cultural background of the foreign-born faculty as to not to exclude them.

Additionally, Chatri spoke about the effectiveness of the mentorship program at his institution, where junior faculty members are paired with more experienced faculty members who can provide insights and support in different aspects of academic life. Many scholars have demonstrated the effectiveness of mentoring programs in faculty development (e.g., Blandet al., 2009; Espino \& Zambrana, 2018; Fountain \& Newcomer, 2016; Zambrana et al., 2015). This study provides further empirical support that mentorship programs can be an effective way in professional and personal development of novice foreign-born transnational teacher-scholars.

Other recommendations for institutions to increase the embeddedness and retention of minority faculty may include:

- Establish a task force to develop a clear mission statement and an action plan to address issues of diversity and equity both on and off campus.

- Decrease minority faculty's sense of isolation by providing opportunities for them to build relationships.

- Create regular venues and Table Talks for minority faculty to meet and socialize.

- Arrange social networking events for faculty and staff from different departments.

- Offer incentives to faculty and administrators to attend these social events.

- Create a multicultural center to promote and celebrate diversity on and off campus; invite guests and speakers from diverse backgrounds.

- Help newly hired minority faculty settle into their new home by offering financial programs such as housing incentives and partnerships with realtors.

- Support the work-life balance of faculty.

- Provide affordable child-care services, child-friendly resources, and activities for the family.

- Promote and encourage self-care.

$\circ$ Offer flexible work hours.

- Provide mental health services on campus. 
- Assess institutional policies that impact work-life balance of faculty such as leave policies and professional development options.

- Allow spousal hire.

- Implement regular community outreach.

- Offer university-community mixers to celebrate diversity and to foster cross-cultural connections on and off campus.

- Develop partnership with community service-providers to promote services and products that may be of interest to minority faculty.

- Offer recognition and reward (such as space-use) to community organizations that promote diversity and cross-cultural activities.

- Conduct on-going assessments of faculty satisfaction to identity needs and concerns.

- Utilize exit interviews or surveys eliciting departing foreign-born faculty's input on ways to increase faculty's embeddedness.

- Regularly evaluate the institution's success of the efforts in the action plan.

Some of these actionable items have been proposed and/or implemented by institutions across the US in an effort to address campus climate and retention issues. For instance, my doctoral institution, Indiana University of Pennsylvania (IUP), which is located in a rural area of Pennsylvania with a population of less than 90,000, reported that IUP's faculty of color expressed great appreciation for "'networking events' where minority faculty could gather, socialize and share their experiences in an informal but institutionally-supported event" (Hildebrandt \& Swauger, 2016, p. 31). Thus, institutional support for foreign-born faculty must go beyond assistance with immigration process (Foote, 2013) and provide assistance in creating a welcoming community, sense of belongingness, and fulfilling relationships.

One particular phenomenon that emerged in the narratives is the rise of nationalism in the US, as a result of which some of the participants (i.e. Maria and Alia) were considering leaving the US for a more immigrantfriendly country. The intersection of academia and nationalism-as well as Trumpism and the current sociopolitical climate - is an important issue with significant implications for higher education institutions. Issues institutions must consider for close examination include how nationalism and Trumpism may affect the identities, perceptions, and experiences of their foreign-born faculty, how scholarship opportunities available to their foreign-born faculty may be affected, how their foreign-born faculty's relations with their students, colleagues, and other members of their community may be impacted, and what type of support may be provided to their foreign-born faculty to increase their sense of safety, belonging, and embeddedness both inside and outside the campus. Attending to these issues does not only 
increase faculty retention and institutions' competitiveness and prosperity, but it is also an ethical responsibility and social function of educational institutions to defend and protect their faculty, both US-born and foreignborn, against injustice and marginalization in turbulent sociopolitical times.

\section{References}

Alberts, H. C. (2008). The challenges and opportunities of foreign-born instructors in the classroom. Journal of Geography in Higher Education, 32(2), 189-203. https://doi.org/10.1080/03098260701731306

Alexander, J. C. (2019). Frontlash/Backlash: The crisis of solidarity and the threat to civil institutions. Contemporary Sociology, 48(1), 5-11. https://doi.org/10.1177/0094306118815497

Atkinson, R. (2002). The life story interview. In J. F. Gubrium \& J. A. Holstein (Eds.), Handbook of interview research: Context \& method (pp. 121-140). Sage Publications.

Bennett, J. (2020). The share of immigrant workers in high-skill jobs is rising in the U.S. Pew Research Center.

https://www.pewresearch.org/fact-tank/2020/02/24/the-share-ofimmigrant-workers-in-high-skill-jobs-is-rising-in-the-u-s

Bland, C. J., Taylor, A. L., Shollen, S. L., Weber-Main, A. M., \& Mulcahy, P. A. (2009). Faculty success through mentoring: A guide for mentors, mentees, and leaders. R\&L Education.

Bookman, B. (2019) The Intersection of transnationality and scholarship: Lived experiences, positionings, and practices of five transnational TESOL teacher-scholars. PhD thesis, Indiana University of Pennsylvania.

Bureau of Labor Statistics. (2020). Foreign-born workers: Labor force characteristics-2019.

https://www.bls.gov/news.release/pdf/forbrn.pdf

Cejda, B. D. (2010). Faculty issues in rural community colleges. New

Directions for Community Colleges, 152, 33-40.

https://doi.org/10.1002/cc.425

Collins, J. M. (2008). Coming to America: Challenges for faculty coming to United States' universities. Journal of Geography in Higher Education, 32(2), 179-188. https://doi.org/10.1080/03098260701731215

Denzin, N. K. (1987). The recovering alcoholic. Sage Publications.

Denzin, N. K. (2014). Interpretive autoethnography (2 ${ }^{\text {nd }}$ ed.). Sage Publications. https://doi.org/10.4135/9781506374697

Du Bois, J. W., Schuetze-Coburn, S., Cumming, S., \& Paolino, D. (1993). Outline of discourse transcription. In J. W. Du Bois, S. Schuetze- 
Coburn, S. Cumming, \& D. Paolino (Eds.), Talking data:

Transcription and coding in discourse research (pp. 45-90).

Hillsdale, NJ: Lawrence Erlbaum Associates.

Espino, M. M., \& Zambrana, R. E. (2018). "How do you advance here?

How do you survive?" An exploration of under-represented

minority faculty perceptions of mentoring modalities. The Review of

Higher Education, 42(2), 457-484.

https://doi.org/10.1353/rhe.2019.0003

Ferren, A. S., \& Merrill, M. C. (2013). The role of institutional research in supporting internationalization of U.S. higher education. Journal of Higher Education Theory and Practice, 13(2), 45-56.

Finkelstein, M. J., Walker, E., \& Chen, R. (2009). The internationalization of the American faculty: Where are we, what drives or deters us?

RIHE International Seminar Reports, 13, 113-144. http://ci.nii.ac.jp/naid/110007456291/en

Foote, K. (2013). Supporting and mentoring international faculty. In H.C. Alberts \& H. D. Hazen (Eds.), International students and scholars in the United States: Coming from abroad (pp. 181-198). Palgrave Macmillan. https://doi.org/10.1057/9781137024473_10

Foote, K. E., Li, W., Monk, J., \& Theobald, R. (2008). Foreign-born scholars in US universities: Issues, concerns, and strategies. Journal of Geography in Higher Education, 32(2), 167-178. https://doi.org/10.1080/03098260701731322

Fountain, J., \& Newcomer, K. E. (2016). Developing and sustaining effective faculty mentoring programs. Journal of Public Affairs Education, 22(4), 483-506. https://doi.org/10.1080/15236803.2016.12002262

Furuya, Y., Nooraddini, M. I., Wang, W., \& Waslin, M. (2019). A Portrait of foreign-born teachers in the United States. George Mason University Institute for Immigration Research. https://d101vc9winf8ln.cloudfront.net/documents/29869/original/Te acher_Paper_FINAL WebVersion 012219.pdf?1548268969

Gahungu, A. (2011). Integration of foreign-born faculty in academia: Foreignness as an asset. The International Journal of Educational Leadership Preparation, 6(1), 1-22. http://cnx.org/content/m36649/1.2

Guarnizo, L. E., \& Smith, M. P. (1998). The locations of transnationalism. In M. P. Smith \& L. E. Guarnizo (Eds.), Transnationalism from below (pp. 3-31). Transaction Publishers.

Hildebrandt, M., \& Swauger, M. (2016). IUP campus climate final report. https://www.iup.edu/socialequity/campus-climate-survey

Kim, D., Wolf-Wendel, L., \& Twombly, S. (2011). International faculty: Experiences of academic life and productivity in U.S. universities. 
The Journal of Higher Education, 82(6), 720-747.

https://doi.org/10.1353/jhe.2011.0038

Leist, J. (2007). "Ruralizing” presidential job advertisements. New

Directions for Community Colleges, 137, 35-46.

https://doi.org/10.1002/cc.268a

Lin, A., Grant, R., Kubota, R., Motha, S., Sachs, G. T., Vandrick, S., \& Wong S. (2004). Women faculty of color in TESOL: Theorizing our lived experiences. TESOL Quarterly 38(3), 487-504.

https://doi.org/10.2307/3588350

Lincoln, Y. S., \& Guba, E. G. (1985). Naturalistic inquiry. Sage Publications.

Mamiseishvili, K. (2013). Contributions of foreign-born faculty to doctoral education and research. New Directions for Higher Education, 163, 89-98. https://doi.org/10.1002/he.20068

Mamiseishvili, K., \& Rosser, V. J. (2010). International and citizen faculty in the United States: An examination of their productivity at research universities. Research in Higher Education, 51(1), 88-107. https://doi.org/10.1007/s11162-009-9145-8

Mitchell, T., Holton, B., \& Lee, T. (2001). Why people stay: Using job embeddedness to predict voluntary turnover. Academy of Management Journal. 44(6), 1102-1121.

Motha, S., \& Varghese, M. M. (2016). Rewriting dominant narratives of the academy: Women faculty of color and identity management. Race, Ethnicity, and Education, (21)4, 503-517. https://doi.org/10.1080/13613324.2016.1248826

Murray, J. P. (2007). Recruiting and retaining rural community college faculty. New Directions for Community Colleges, 137, 57-64. https://doi.org/10.1002/cc.270

National Immigration Law Center. (2019). One year after the SCOTUS ruling: Understanding the Muslim ban and how we'll keep fighting it. https://www.nilc.org/issues/immigrationenforcement/understanding-muslim-ban-one-year-after-ruling

Patton, M. Q. (2002). Qualitative research and evaluation methods. Sage Publications.

Purkayastha, B. (2005). Negotiating ethnicity: Second-generation South Asian Americans traverse a transnational world. Rutgers University Press.

Schuster, J. H., \& Finkelstein, M. J. (2006). The American faculty. Johns Hopkins University Press.

Schmidt, P. W. (2019). An overview and critique of US immigration and asylum policies in the Trump era. Journal on Migration and Human Security, 7(3), 92-102. https://doi.org/10.1177/2331502419866203 
Skachkova, P. (2007). Academic careers of immigrant women professors in the U.S. Higher Education, 53, 697-738. https://doi.org/10.1007/s10734-005-1976-4

Stephan, P. E., \& Levin, S. G. (2001). Exceptional contributions to US science by the foreign-born and foreign-educated. Population Research and Policy Review, 20(1-2), 59-79. https://doi.org/10.1023/A:1010682017950

Tang, J. (2000). Doing engineering: The career attainment and mobility of Caucasian, black and Asian-American engineers. Rowman \& Littlefield Publishers.

Theobald, R. (2013). International faculty: A source of diversity. In H.C. Alberts \& H. D. Hazen (Eds.), International students and scholars in the United States: Coming from abroad (pp. 111-130). Palgrave Macmillan. https://doi.org/10.1057/9781137024473 6

Toth, E. (2007). Women in academia. In A. L. Deneef \& C. D. Goodwin (Eds.), The academic's handbook (pp. 47-61). Duke University Press.

Tripp, D. (2012). Critical incidents in teaching: Developing professional judgement (Classic ed.). Routledge.

Turner, C., González, J.C., \& Wood, J. (2008). Faculty of color in academe: What 20 years of literature tells us. Journal of Diversity in Higher Education, 1, 139-168.

United States Census Bureau (2020). Foreign born. https://www.census.gov/topics/population/foreign-born/about.html

Varma, R. (2006). Harbingers of global change: India's technoimmigrants in the United States. Lexington Books.

Waldinger, R. (2008). Between "here" and "there": Immigrant cross-border activities and loyalties. International Migration Review, 42(1), 329. https://doi.org/10.1111/j.1747-7379.2007.00112.x

Webber, K. L. (2012). Research productivity of foreign- and US-born faculty: Differences by time on task. Higher Education, 64, 709729. https://doi.org/10.1007/s10734-012-9523-6

Witherspoon Arnold, N., Crawford, E. R., \& Khalifa, M. (2016).

Psychological heuristics and faculty of color: Racial battle fatigue and tenure/promotion, The Journal of Higher Education, 87(6), 890919. https://doi.org/10.1080/00221546.2016.11780891

Zambrana, R. E., Ray, R., Espino, M. M., Castro, C., Cohen, B. D., \& Eliason, J. (2015). Don't leave us behind: The importance of mentoring for underrepresented minority faculty. American Educational Research Journal, 52(1), 40-72. https://doi.org/10.3102/0002831214563063 


\section{Appendix: Excerpt from the Written Questionnaire and Interviews}

\section{Critical Incidents}

Please describe 5 events you've experienced related to your transnational lived experiences, and/or teaching, research, or service in the United States. Please note:

- The events may be commonplace or routine. They do not have to be dramatic.

- The events must have had a special significance or lasting effect on you as a transnational or as a teacher-scholar.

- The events may have been a positive or negative experience.

- You may have been directly involved in the event, or you may have been an observant.

* Feel free to use any genre or form that you'd like. For example, you may write narratives, write poems, make a collage, draw, or use photos to represent the events and how they impacted you.

\section{Reflection Questions:}

1) What challenges have you experienced as a [foreign-born] faculty?

2) Are there any social or political issues or realities you've recently encountered that have surprised you or challenged your values?

3) Has the recent political climate ever made you consider relocation?

4) How do you think higher-education institutions can attract and retain highly qualified [foreign-born] transnational faculty?

\footnotetext{
Author Bio

BITA BOOKMAN, Ph.D. is an ESL faculty at Santa Rosa Junior College. She has been teaching graduate and undergraduate courses in several countries and has presented at numerous national and international conferences. Her research interests include the intersection of transnationality and teacher identities, faculty perceptions and practices, and second language pedagogy and assessment.
} 